\title{
Afgrænsningen mellem sand og falsk skrifttolkning hos Irenæus og Grundtvig
}

\author{
Af Anders-Christian Jacobsen
}

Irenæus har efter alle grundtvigforskeres mening spillet en vis rolle for Grundtvig. Efter min mening har han spillet en helt afgørende rolle. De fleste, der har undersøgt forholdet mellem Irenæus og Grundtvig, har fokuseret på, hvordan Grundtvig har overtaget en række teologiske motiver fra Irenæus. ${ }^{1}$ Derimod er der ikke nogen, der har gjort ret meget ud af Irenæus' betydning for Grundtvigs »mageløse opdagelse « af trosbekendelsens betydning som sammenfatning af troens indhold og $\mathrm{i}$ forlængelse heraf som kriterium for den rette tolkning af bibelen. Jeg mener imidlertid præcist at kunne sige, hvordan og hvornår Grundtvig er blevet inspireret af Irenæus' på dette punkt. ${ }^{2}$ Men hvorfor er det interessant? Det er det, fordi bibelen hos dem begge spillede en afgørende rolle som kilde til, hvad kristendom er. Samtidig blev de begge udfordret at folk, der forstod og fortolkede bibelen anderledes end dem selv. Derfor blev spørgsmålet om bibelens autoritet og dens rette fortolkning akut for dem, hvilket hos dem begge førte til en dybtgående teologisk gennemtænkning af denne problematik. Det er bl.a. denne kamp for den rette skrifttolkning, der forbinder Irenæus og Grundtvig. Det skal jeg prøve at belyse nærmere i det følgende ved først ganske kort at undersøge, hvilke kriterier Irenæus opstiller for bibeltolkningen og dernæst, hvordan Grundtvig lader sig inspirere heraf.

\section{Irenceus $^{3}$}

Irenæus levede fra ca. 130 - ca. 200. Han stammede fra Lilleasien, men flyttede på et tidspunkt til Lyon i Gallien, hvor han først blev presbyter og senere biskop (177 e.Kr.). Irenæus har skrevet flere teologiske værker, hvoraf to er overleveret til eftertiden. Det største og vigtigste skrift er hans skrift mod kætterne i fem bøger, som kaldes Adversus haereses (Adv. haer.). ${ }^{4}$ Det andet skrift er et mindre skrift, som indeholder en sammenfatning af troslæren, og som sikkert har været brugt i forbindelse med dåbsoplæringen (katekumenatet). Dette skrift hedder »Bevis for den apostolske forkyndelse«, forkortet 
Epideiksis. ${ }^{5}$ Derud over har han skrevet flere andre teologiske værker, som er gået tabt for eftertiden.

De kættere, som Irenæus' teologiske hovedværk er vendt imod, er gnostikerne. I Adversus haereses' første bog beskrives en lang række gnostiske retninger og deres lære. Størst opmærksomhed vier han den valentinianske gnosis, som var en stor bevægelse, med et omfattende og kompliceret teoretisk grundlag. Denne gnostiske retning hører, som de fleste af de retninger, Irenæus beskriver, til den såkaldte »kristne " gnosis. Det vil sige, at disse gnostikerne selv betragter sig som kristne - endda som de eneste rigtige kristne -, og at de i høj grad begrunder deres lære ud fra den bibelske tradition. Det er ifølge Irenæus netop det, der er farligt: de optræder og taler, som om de var kristne, men det er de ifølge Irenæus ikke. De er ulve i fåreklæder. Det er denne konflikt, der ligger bag Irenæus' overvejelser over, hvordan de bibelske skrifter fortolkes ret.

\section{Irenaus' kriterier for skrifttolkningen}

I Adv. haer. findes der mange eksempler på, hvordan Irenæus går i rette med gnostikernes tolkning af de bibelske skrifter. I denne sammenhæng tager jeg blot et af disse eksempler frem, nemlig Adv. haer. 1,1-1,10.

Irenæus indleder Adv. haer. med en lang beskrivelse af valentinianernes kosmologi, antropologi og forløsningslære og en efterfølgende kritik heraf, som især er koncentreret om den skrifttolkning, som de underbygger deres lære med (Adv. haer. 1,1,1-1,10,3). Perikopen indledes med en beskrivelse af valentinianernes kosmologi (Adv. haer. 1,1-1,2,6). Grundstenen i denne kosmologi er meget kort fortalt, at det trancendente kosmos - Pleromaet - består af en lang række (30) æoner - en form for kosmiske guddomme eller guddommelige væsener -, der parvis, mandlig og kvindelig, er ordnet i et kompliceret system efter et princip om, at det $\emptyset$ verste æonpar efter et samkvem beskrevet i seksuelle vendinger frembringer de underliggende æoner, der så igen frembringer endnu andre æoner o.s.v. Hele dette system søger valentinianerne at underbygge med henvisninger til de bibelske skrifter. I Adv. haer. 1,3,1-6 gennemgår Irenæus de bibeltekster, som valentinianerne anfører som bevis for denne kosmologi. F.eks. begrunder valentinianeme eksistensen af en bestemt gruppe på 12 æoner 
med beretningen om, at Jesus var 12 år, da han diskuterede med de lærde i templet (Adv. haer. 1,3,2, jvf. Luk. 2,41-52), og med beretningen om Jesu udvælgelse af de tolv disciple (Adv. haer. 1,3,2, jvf. Luk. 6,12-16). Gnostikerne finder således i disse bibeltekster en dybere betydning, som ikke er tilgængelig for alle men kun for dem, der har specielle kvalifikationer til at forstå denne dybere betydning, d.v.s. gnostikerne selv, der er i besiddelse af den frelsende erkendelse (gnosis). Det vil sige, at de bibelske tekster forvandles til esoteriske tekster, hvis betydning kun er tilgængelig for dem, der besidder den specielle kundskab. Denne søgen efter en dybere og hemmelig betydning af bibelteksterne vender Irenæus sig kraftigt imod.

Efter gennemgangen af de tekster, som gnostikerne bruger som bevis for deres kosmologi, følger så i Adv. haer. 1,4,1-1,7,5 en gennemgang af valentinianernes lære om det, der er uden for Pleromaet, det vil først og fremmest sige den materielle verden, mennesket og demiurgen, som er skaberen af det materielle, samt en beskrivelse af valentinianernes soteriologi. Hovedpunkterne i deres lære om det, der er uden for æonsystemet, er, at den materielle verden er blevet til som et resultat af den 12. æon, Sofias, oprør, der medførte, at denne kvindelige æon faldt, så at sige neden ud af systemet. Hendes sorg og vrede herover er den substans som demiurgen, den uvidende skabergud, skabte den materielle verden af. I de materielle legemer, der blev skabt, blev der indplantet en gnist af det guddommelige. Menneskets frelse og befrielse består derfor $\mathrm{i}$, at denne gnist forløses fra fangenskabet $\mathrm{i}$ det materielle, så den kan vende tilbage til sit udspring i Pleromaet. Også denne beskrivelse af valentinianernes lære efterfølges af en redegørelse for, hvilke bibeltekster valentinianerne anfører i denne sammenhæng (Adv. haer. 1,8,1-1,8,5). Det drejer sig f.eks. om beretningen om synagogeforstanderens tolvårige datter, der blev opvakt af Jesus (Luk. 8, 40-56), der tolkes som et billede på den tolvte æon, Sofias, lidelse og tilbageføring til Pleromaet; og om beretningen om det fortabte får (Luk. 15,4-7), der ifølge gnostikerne er et billede på det samme.

Denne beskrivelse af valentinianernes lære og gennemgangen af deres skriftbeviser herfor følger Irenæus op med en mere principiel kritik af deres eksegese. Det sker i Adv. haer. 1,8,1-1,10,3. Hovedpunkterne i denne kritik anføres i Adv. haer. 1,8,1: For det første anklager Irenæus gnostikerne for, at deres lære stammer fra andre kilder end bibelen. Hverken profeterne (d.v.s. G.T.), Herren selv, eller apostlene 
har lært noget sådant. Når de så bruger de bibelske tekster som bevis for denne for bibelen fremmede lære, ser de bort fra den sammenhæng, som de bibelske tekster indgår i. Derved får teksterne en anden betydning. Denne kritik illustrerer Irenæus i det følgende med to meget sigende billeder eller lignelser, om man vil.

Den første lignelse, som findes i Adv. haer. 1,8,1 handler om, hvordan et meget smukt billede af en konge brydes itu, hvorefter mosaikkens sten sammenstilles på en ny måde, denne gang af en dårlig kunstner. Det nye billede forestiller en ræv. Den, der nu betragter billedet, genkender de ædle sten fra det oprindelige kunstværk. Dem, som ikke ved, hvordan kongen så ud, kan heraf forledes til at tro, at billedet af ræven, virkelig er kongens billede. Således er det også med gnostikernes skriftbrug: de anvender nok ægte citater fra de bibelske skrifter, men den måde, hvorpå de behandler udsagnene medfører, at deres fortolkning bliver falsk. Irenæus beskylder altså gnostikerne for en atomiserende "mannakornslæsning " af de bibelske skrifter, hvis formål ikke er at tolke de bibelske tekster, men derimod at give deres egen lære, der ikke stammer fra bibelen, et troværdigt skin.

Lignelsen i Adv. haer. 1,8,1 har en parallel i Adv. haer. 1,9,4. Her viser Irenæus, hvordan en samling homér-citater fra Illiaden og Odyssén kan sammenstilles til en ny beretning, der nok af skin er en homér-tekst, men som alligevel er en forfalskning. Gnostikernes bibelbrug sammenlignes med en sådan brug af Homér. Pointen er igen, at en sådan brug af såvel Homér som af bibelen er forfalskning, der kan lede den ulærde vild.

Det nye, der kommer til i Adv. haer. 1,9,4 i forhold til lignelsen i Adv. haer. 1,8,1 er Irenæus' anvisning på, hvordan og af hvem det gnostiske falskneri kan gennemskues. Svaret ligger allerede i luften: falskneriet kan gennemskues, hvis man kender sammenhængen i og essensen af de bibelske skrifter. Irenæus' svar er imidlertid mere komplekst end som så. Han nøjes nemlig ikke med at henvise til et grundigt skriftstudium som svar på gnostikernes forvanskning af skriften. Han henviser derimod til »sandhedens regel« (regula veritatis) ${ }^{6}$, som nøglen til den rette forståelse og fortolkning af skriften: Den der bevarer »sandhedens regel «, som han modtog ved dåben, uforvansket i sit hjerte, han kan gennemskue gnostikernes falske brug af skriften, og således placere de løsrevne skriftcitater i deres rette sammenhæng, hvorved deres sande betydning kommer til syne. Den 
rette skrifttolkning er altså ikke alene og ikke først og fremmest resultatet af den enkeltes grundige skriftstudium. Det kan ende i vilkårligheder, som det er sket for gnostikerne. Den rette forståelse og fortolkning af bibelen er derimod resultatet af, at den enkelte kristne gennem sin dåb indoptager essensen af kirkens tradition i sig, og bruger denne tradition som kriterium for såvel egen som andres skrifttolkning. Der er ikke tale om, at den kristne gennem dåben bliver indviet $i$ en hemmelig tradition eller mystiske sandheder men om, at dåben forudsætter en oplæring (katekumenatet) i de grundlæggende elementer i kirkens tro, som er sammenfattet $\mathrm{i}$ »sandhedens regel «. Når den kristne kender disse grundlæggende elementer i den kristne tro, er han ifølge Irenæus også i stand til at se, hvad der er sand, og hvad der er falsk tolkning af bibelen. Disse grundlæggende elementer i kirkens tro er nemlig essensen af kirkens fælles tolkning af bibelen og af den mundtligt overleverede tradition. Disse to åbenbaringskilder er for Irenæus identiske, idet der blot er tale om, at den samme sandhed udtrykkes i to forskellige »medier«. Hvad Irenæus fordrer er derfor, at skriften fortolkes »i kirken hos presbyterne og biskopperne « (Adv. haer. 4,32,1), fordi de er bærer af kirkens tradition. Essensen af dette er altså et krav om, at enhver fortolkning af bibelen skal have traditionen som kriterium og rettesnor. Denne tradition, som er fælles for hele kirken, er sammenfattet $\mathrm{i}$ den såkaldte "sandhedens regel «, som der gives et eksempel på i Adv. haer.1,10,1. Derfor kan Irenæus i Adv. haer. 1,9,4 hævde, at sand og falsk bibeltolkning kan skelnes fra hinanden med "sandhedens regel« som kriterium. Det er, som jeg skal vise i det følgende, denne brug af »sandhedens regel«, der har inspireret Grundtvig til hans »mageløse opdagelse « af, at Den apostolske Trosbekendelse kan bruges som kriterium for den rette tolkning af bibelen.

\section{Grundtvig}

Min tese for den følgende beskrivelse af Grundtvigs søgen efter normer og kriterier for skrifttolkningen er, at Grundtvig meget tidligt blev foruroliget over den rationalistiske teologi og især dens bibelkritik. Det var arbejdet med at forholde sig til og tilbagevise denne rationalistiske teologi og bibelkritik, der ledte frem til den såkaldte »mageløse opdagelse« i 1825. I slutningen af denne proces $\mathrm{i}$ årene 
kort før 1825 kom Irenæus til at spille en afgørende rolle for Grundtvig, idet han hos ham fandt de afgørende argumenter mod rationalisternes bibeltolkning.

Denne tese bygger i første omgang på Grundtvigs egne erindringer $^{7}$ om perioden frem til 1825. Disse erindringer er nedskrevet $i$ vinteren 1862-63. Det er således den gamle mands tilbageblik over begivenheder i længst svundne tider, der kommer til udtryk. Den gamle Grundtvigs erindringer om begivenhederne i begyndelsen af århundredet står sikkert i forklarelsens lys, farvet af de erfaringer, som han har gjort i den mellemliggende tid. Derfor vil det være metodisk ukorrekt umiddelbart at tage disse udsagn fra Grundtvigs erindringer for gode varer. De må efterprøves ved at undersøge konkrete tekster fra Grundtvigs hånd fra den pågældende periode. Jeg skal derfor fors $\varnothing$ ge at belyse følgende punkter: 1) Forløbet af Grundtvigs kritik mod rationalisterne fra begyndelsen af århundredet frem til begyndelsen af 1820 'erne. 2) Den »mageløse opdagelse« og Irenæus' betydning herfor.

\section{Grundtvigs kamp mod rationalismen ${ }^{8}$}

Grundtvig indleder sine kirkelige erindringer med en beskrivelse af den danske kirkes situation i tiden omkring sin fødsel i 1783. Han henviser til den omstændighed, at Balle netop i dette år blev Sjællands biskop. Balle opfattede sig selv som den lutherske statskirkes forsvarer, men var efter Grundtvigs mening netop det modsatte, idet hans manglende styrke og situationsfornemmelse gav kirkens modstandere, d.v.s. rationalisterne, frit spil til at indføre deres kirke og kristendomsfjendske lære. Disse angreb på kirke og kristendom fik ifølge Grundtvig bl.a. sine konkrete nedslag i, at Balle i 1890'erne fik indført sin »meget ulutherske og kun lidet kristelige Lærebog i hele Rigets Almueskole« (Erindringer, s. 87); at den »kun saakaldte »evangeliske« Salmebog « (Erindringer, s. 87) blev indført som afløser for Kingos salmebog; og at Balle fik oprettet et lærerseminarium med rent ukristelige lærere. Ligeså anklager han Balle for at binde de teologiske studenter til professorerne i København, der indpodede deres disciple tvivl og vantro (Erindringer, s. 87-88). Sådan var den kirkelige situation i tiden omkring Grundtvigs fødsel. Af Grundtvigs erindringer fremgår det, at han opfatter denne si- 
tuation, præget af de rationalistiske angreb på kirke og kristendom som forståelseshorisont for sit teologiske og kirkelige virke.

Denne kirkelige og teologiske situation havde Grundtvig - igen efter eget udsagn - allerede stiftet bekendtskab med hos pastor Feld i Thyregod, hvor han opholdt sig fra 1792-98. Der havde han læst såvel Horrebovs "Jesus og fornuften « som Balles »Bibelen forsvarer sig selv«. Derudover havde hans også læst i københavnske flyveskrifter, »som gjennem et Læseselskab i Vejle fløj rundt paa Heden « (Erindringer, s. 88). Denne læsning havde bragt ham til den konklusion, at »det kunde nok være værdt at hjælpe Biskop Balle, der stod saa enlig, lidt med at læse de Spyttegjøge og Spottefugle Texten« (Erindringer, s. 88). Grundtvig har altså allerede i drengeårene stiftet et ret indgående bekendtskab med oplysningsteologiens og rationalismens kritik af den overleverede kirke og kristendom.

Grundtvigs interesse for kirke og kristendom døde imidlertid hen i tiden på Århus Katedralskole og i studietiden i København. Det var således uden lyst, at han studerede teologi. Han tilsluttede sig endog en overgang de rationalistiske grundsynspunkter. Spørgsmålet er dog, hvor dybt denne tilslutning til rationalismen stak, og især hvor længe denne rationalistiske periode varede. Sædvanligvis antager man vel, at hans manglende interesse for kirkelige forhold stort set varede frem til de begivenhedesrige år 1810-11, hvor han vendte tilbage til faderens gammellutherske kristendomssyn. Imidlertid skriver Grundtvig allerede i 1806, mens han opholder sig på Langeland, en længere afhandling: »Om Religion og Liturgie «", hvor han går stærkt i rette med de rationalistisk sindede kredses fors $\emptyset \mathrm{g}$ på at få indført en ny liturgi i oplysningens ånd. Denne afhandling er præget af hans daværende tiltrækning af romantikken og den tyske idealisme. Det er sikkert den væsentligste baggrund for hans kritik såvel af den herskende liturgiske praksis som af forslaget til en ny liturgi. Begge er ifølge Grundtvig udtryk for $\emptyset$ nsket om, at fjerne det oversanselige fra kristendommen (Om Religion og Liturgie, V.U., bd. 1, s. 130).

Grundtvig giver dog også i denne afhandling udtryk for, at hverken filosofiens eller poesiens stræben efter det evige kan vise vejen til det endeliges forsoning med det evige, som er pointen i den kristne religion. Åbenbaringen i Kristus er nødvendig (Om Religion og Liturgie, V.U., bd. 1, s. 112-13). Ligeså hævder han, at enhver liturgi i den kristne kirke må bygge på de anvisninger, som findes $\mathrm{i}$ apostlenes skrifter (Om Religion og Liturgie, V.U., bd. 1, s. 123-24). 
Allerede i 1806 kan man altså hos Grundtvig finde en kritik af rationalismen, der først og fremmest bygger på inspiration fra romantikken og idealismen, men som også indeholder henvisninger til apostlenes lære som norm.

I 1810 indtraf der afgørende begivenheder, som medførte, at Grundtvig langt mere intensivt måtte forholde sig til den kristendom og den kirkelige virkelighed, der omgav ham. Disse begivenheder havde udspring i faderens $\varnothing$ nske om at få Grundtvig hjem til Udby som kappelan. Grundtvig var modvillig. Han havde tilsyneladende en lovende karriere som skribent foran sig, og var derfor helst blevet $\mathrm{i}$ København. Han indvilligede dog, og holdt derfor sin prøveprædiken, den såkaldte »dimisprædiken« i marts 1810. Den udgav han i maj 1810 under titlen: "Hvi er Herrens Ord forsvundet af hans Hus? «. ${ }^{10}$ Prædikenen indeholder skarpe udfald mod de rationalistiske præster og deres prædiken. Et par citater er nok til at karakterisere både stil og indhold. Efter en henvisning til, hvordan Herrens ord er blevet overleveret gennem slægterne helt til vor tid hedder det: »..., selv vi have annammet det af vore Fædre, og skulle gjennem Børn og Børnebørn nedsende det til de sildigste Slægter. Vi skulle, men gjøre vi det ogsaa? Trænger Jesu hellige Navn fra den bedende Faders og Moders Læbe ind i Barnets Øre og Sjæl, fremstilles og prises Frelseren i vore Forsamlinger som Guds Herligheds Glans og Jorderigs Sol? Sønderknusende er det at maatte nægte det, men nægtes maa det. Som en Lyd uden Værd og Betydning høre de yngre iblandt os Jesu navn almindelig at nævnes, ja stort maa vi kalde det, naar de kun høre det saa, naar det ej kommer til dem, svøbt i Bespottelse og Haan. Og nu vore Kirker, jeg siger vore, thi Kristi er de ej længer, hvad høres vel der? Hel ofte forfængelig Snak om alskens Smaating paa Jord, og kommer det højt, da brammende Ord og kløgtige Taler, men idel Lærdomme, som kun. ere Menneskens Bud. Herrens Ord er forsvundet af hans Hus, thi naar det og lyder, er det ikke det, som høres, som udlægges og indskærpes, det maa lade sig forvende og bruge til hos den enfoldige at styrke Menneskers Mening « (B.P., s. 13-14). Lidt sener hedder det: »..., og saaledes skete det, at Lutherdommen, hvis særegne det i Stifteren var og stedse skulde være, at løfte den hellige Skrift højt over al menneskelig Myndighed, at selv den maatte føde Ringeagt for det hellige. Ved hvert Skridt, Menneskeaanden gjorde til en lysere Erkjendelse af Tingene trindt os, af Naturen og dens Love, og af sin egen Virkemaade, trode den sig stedse mere 
beføjet til at være klog over det, som skrevet står« (B.P., s. 17). Grundtvig kritiserer her sin samtids kirkelighed, d.v.s. rationalisterne, for at sætte menneskelig myndighed og klogskab over det, som står skrevet i bibelen. Han fremtræder som fortaler for en ortodoks lutherdom overfor samtidens selvklogskab. Det er denne linie, han følger i de kommende år, hvor han p.g.a. sin åndelige krise i slutningen af 1810 vender hjem til faderen i Udby og senere i 1811 bliver hans kappelan. Det kommer, som han selv påpeger i sine erindringer (Erindringer, s. 96-97), bl.a. til udtryk i hans Kort Begreb af Verdens Krønike i Sammenhæng “, som udkom i 1812." Dette skrift er en tendentiøs fremstilling af historiske begivenheder og personer ud fra kriteriet om, hvorvidt de befordrer eller hæmmer den sande kristendom. Den hårdeste kritik rettes mod oplysningsteologien og oplysningfilosofien, som bl.a. kritiseres for at undergrave bibelen v.h.a. en forvansket skriftkritik. ${ }^{12}$ Tonen og anliggendet er det samme som i demisprædikenen. Samme linie fortsættes efter hans tilbagevenden til København i 1813. Her prædiker han lejlighedsvis indtil 1815, hvorefter han opgiver sin prædikenvirksomhed. I en af de sidste prædikener ${ }^{13}$ fra denne periode finder man en kritik af rationalismen, der ligner den, som kom til udtryk i Demisprædikenen og i Verdens Krøniken. Prædikenen, der har overskriften: »Salige ere de, som høre Ordet og bevare det! «, består således først og fremmest af en langstrakt kritik af dem, der ikke vil tro Herrens undere, men i stedet forklare dem med fornuften, og af dem, som fordrejer og fornægter Frelserens ord. Og ikke mindst dem, der på trods af deres læreembede ikke forkynder Herrens ord. Kritikkens adresse er også i denne prædiken klar og entydig: Det er oplysningen, rationalismen, der er skurken. Det er altså karakteristisk for denne periode, at Grundtvig til stadighed kritiserer den rationalistiske teologi og prædiken. Det sker ud fra et gammelluthersk synspunkt, hvor troskab mod skriften og den bibelsk funderede prædiken fremholdes som alternativ til rationalisternes »fornuftige « forkyndelse. Det er således klart, at Grundtvig omkring 1815 nok har stillet diagnosen på kirkens sygdom, men han har ikke fundet en virksom medicin. Han har overtaget et traditionelt gammelluthersk standpunkt, som han imidlertid ikke kan gøre til sit eget, og som han ikke kan vinde gehør for i offentligheden. Måske er det en af grundene til, at han opgiver sin prædikantvirksomhed i 1815 . Hans eget svar begynder først at tage form fra begyndelsen af $1820^{\prime}$ erne, hvor han får eget embede, og 
derfor bliver tvunget til at forholde sig til, hvordan der skal prædikes, og hvordan bibelen skal fortolkes.

Tiden fra 1815-21 bruger Grundtvig fortrinsvis til historiske arbejder for om muligt ad denne vej at vække den danske kirke og det danske folk. Fra 1821, hvor han får embede i Præstø, prædiker han igen regelmæssigt.

Grundtvigs prædikener fra 1821 og frem bærer vidnesbyrd om, at han stadig og endnu mere intensivt er optaget af spørgsmålet om, hvordan den rationalistiske bibeltolknings relativering af bibelens sandhed og troværdighed kan imødegås af en bibeltolkning og prædiken, der skaber fast grund under fødderne på de kristne, hvis tro ellers rystes. I denne sammenhæng vil jeg fokusere på et bestemt fænomen i Grundtvigs prædikener fra denne periode, som bl.a. Thodberg har fremhævet ${ }^{14}$. Det drejer sig om nogle bekendelsesagtige indslag i prædikenerne.

Disse bekendelsesagtige indslag i prædikenerne fremstår ifølge Thodberg i prosadigtets form. Det hænger igen ifølge Thodberg sammen med Grundtvigs brug af billedsproget, som ifølge ham er det medium, hvorigennem forbindelsen mellem himmel og jord kan knyttes. ${ }^{15}$ Denne brug af billedsproget og poesien i prædikenerne går helt tilbage til 1813, men udvikles først fra 1821 og frem. Det er nærliggende at antage, at selve denne brug af billedsproget og poesien er Grundtvigs fors $\varnothing \mathrm{g}$ på et svar på rationalismens »fornuftige « og relativerende bibeltolkning. Dette interessante aspekt må jeg imidlertid lade ligge her og i stedet fokusere på de bekendelsesagtige indslag i prædikenerne, idet de peger direkte frem mod Grundtvigs møde med Irenæus og »den mageløse opdagelse «. I prædikenen på Allehelgensdag 1821 - altså i Præst $\varnothing$ - forekommer et sådant bekendelsesudsagn i prosadigtets form. Det indføres med et citat fra 2. Sam. 23, der tolkes som en profeti om Kristi komme. Begyndelsen af udsagnet lyder således:

»Det skedte som han talede,

thi den Retfærdige kom

at retfærdiggiøre Mange

og opfoer igien i det Høie,

at herske med Retfærdigheds Spir

over Menneskens Børn,

Han var som Lys om Morgenen 
naar Soel opgaar

naar der er ingen Skyer paa Himlen

og Græsset i Enge

glindser efter Regnen,

thi det var som skrevet staar,

Morgen-Røden fra det Høie

som besøgde os i Christo Jesu,

og skabde en velsignet Morgenstund for Sjælene,

da Naade-Solen giennembrød

Guds Vredes Tordenskye,

og et nyt Paradis opblomstrede

ved Himmel-Dugg i de Troendes Hjerte.

Ja, det skedte, som David bad:« o.s.v. ${ }^{16}$

Der er tale om en poetisk gengivelse af 2. trosartikels indhold. Prædikenen videreføres ved, at Grundtvig tager temaet tak op med udgangspunkt i prosadigtets 4 . sidste strofe. Både fortidens og nutidens kristne må takke Herren for hans velgerninger. Grundtvigs tilhørere må især takke Herren, fordi også danskerne blev kristne. Det leder frem til en længere udredning om kristendommens historie specielt med henblik på Danmark. Denne beskrivelse har følgende led: Ros til Ansgar, ris til katolikkerne, ros til Luther og ris til oplysningsteologien, der indførte et »fornuftigt Hedenskab $\ll .{ }^{17}$ Det historiske rids sluttes med en henvisning til, at Guds grundvold står fast og et udblik til den futurisk-eskatologiske trængsel. Spørgsmålet er nu, hvad Guds faste grundvold, som altid står, er? Det er vel det, som profeten forkyndte, og som Herren lod ske - altså indholdet af den prosa-poetisk formulerede bekendelse. Hvis Grundtvigs tankegang kan forstås sådan, betyder det, at Grundtvig allerede i 1821 har en spirende forståelse for bekendelsens funktion som en prægnant formulering af det centrale i det kristne evangelium, der kan modstå det »fornuftige hedenskabs « relativerende bibeltolkning.

På 4. søndag i advent $1823^{18}$, hvor prædiketeksten er Joh. 1,1920 (Joh. Døbers prædiken), indføjer Grundtvig også en poetisk formulering af trosbekendelsens andet led i sin prædiken. Grundtvig tager sit udgangspunkt $\mathrm{i}$ tekstens sidste vers: »Dette skete i Betania på den anden side af Jordan, hvor Johannes døbte«. Det skal indskydes, at Betania i Christian d. VII's bibel hedder Bethabara. Grundtvig indleder med retorisk at spørge tilhørerne, om de tror, at 
hans hensigt er at fortælle, hvor uenige de lærde er om, hvor Bethabara lå, hvad ordet betyder o.s.v. Han svarer selv: »Nei, det veed vist alle mine Tilhørere, det faar jeg sidst i Sinde, med mindre det skulde være for at beklage, at det gaaer tit med de hellige Skrifters Forklaring, som Herren sagde: de afsie Myggen og nedsluge Kamelen, forklare nøie hvad ingen Forklaring behøver, og lade uberørt hvad der trængde mest til at oplyses og udlægges «. ${ }^{19}$ Grundtvig vil ikke fortolke bibelen som de lærde, altså rationalisterne. Men hvad så? Han fremhæver først det forunderlige i, at noget, der skete på et så ubetydeligt sted som Bethabara, har fået verdens historisk betydning. Det leder til spørgsmålet om, hvad det var, der skete? Det var Johannes, der prædikede. Men skulle denne begivenhed blive til evangelium for hele folket, måtte der mere til end Johannes. Begivenheden blev da også kun til evangelium, fordi det var indledningen til noget større. Det er dette større, som Grundtvig formulerer som en poetisk gengivelse af indholdet i 2 . trosartikel: Det hedder:

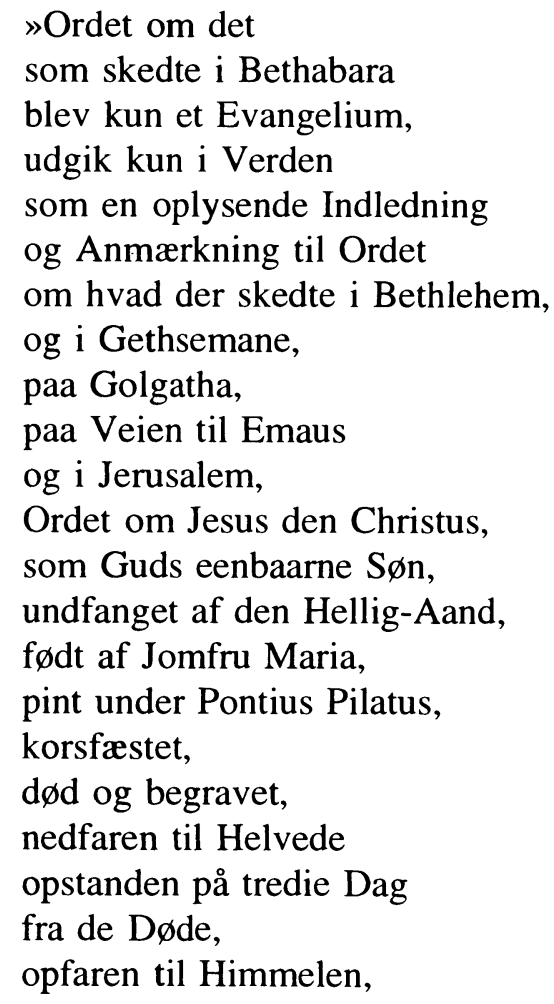


siddende hos Guds høire Haand, hvorfra Han skal igien komme, at dømme Levende og Døde ${ }^{20}{ }^{20}$

Vi ser altså igen, hvordan kritikken af rationalisternes bibeltolkning forbindes med en bekendelsesagtig formulering af, hvad der er essensen $\mathrm{i}$ evangeliet.

Thodberg hævder, efter min mening med rette, at disse bekendelsesagtige formuleringer kan ses som en forberedelse til den »mageløse opdagelse « af trosbekendelsens betydning i $1825 .{ }^{21}$ Forbindelsen mellem disse bekendelsesagtige formuleringer og kritikken af de lærde rationalisters bibeltolkning berettiger endvidere, så vidt jeg kan se, til at hævde, at det netop er denne polemik mod rationalisterne, der allerede i begyndelsen af $1820^{\prime}$ erne leder Grundtvig på sporet af trosbekendelsens funktion som sammenfatning af evangeliet indhold og som kriterium for bibeltolkningen. At trosbekendelsen kan have denne funktion, kommer til at stå helt klart for Grundtvig gennem mødet med Irenæus' teologi.

Denne gennemgang af udviklingen i Grundtvigs polemik mod rationalisterne frem til 1825 er naturligvis ikke udtømmende. Jeg har alene fors $\varnothing \mathrm{gt}$ at tegne en linie v.h.a. Grundtvigs egne erindringer og nogle få udvalgte tekster fra perioden. En mere detaljeret gennemgang af især prædikenerne fra begyndelsen af 1820'erne og af de forsvarsskrifter for kristendommen ${ }^{22}$, som Grundtvig har affattet i denne periode, ville være nyttig. Men holder denne skitse, så består Grundtvigs ballast ved mødet med Irenæus' teologi bl.a. i en endnu uforløst anstrengelse for at overvinde den fare, som han ser i den rationalistiske bibelkritik. Han har dog måske, som prædikenerne fra begyndelsen af 1820'erne antyder, en anelse om, hvor løsningen findes, men klarheden kommer ført ved mødet med Irenæus' teologi.

\section{Grundtvigs »magelфse opdagelse og Irenaus' betydning herfor ${ }^{23}$}

Den »mageløse opdagelse « var ifølge Grundtvigs egne erindringer en epokegørende begivenhed (Erindringer, s. 104-06). I sine erindringer beskriver han således, hvordan han var »...falden i dybe Tanker over den fortvivlede Stilling, hvori Kristi Menighed, og navnlig alle dens Børn og ulærde Medlemmer, var kommet derved, at næsten alle de 
Skriftkloge trodsig paastod, at ikke alene den hellige Skrifts Oprindelse, Omfang og Ægthed og rette Fortolkning var meget tvivlsomme, men at de kirkelige Grund-Lærdomme om Treenigheden, Kristi Guddom og Forsoningen, naar man var Grund-Sprogene mægtig og saae ret til, slet ikke fandtes i Bibelen, som hos alle Protestanter jo dog var Troens eneste Hjemmel« (Erindringer, s. 104). Som det er fremgået af den forudgående redeg ørelse for udviklingen frem til 1825, er denne bekymring ikke så ny, som udsagnet her kunne tyde på. Ny, skønt måske forberedt i de nærmest forudgående år, er derimod det svar på problemet, som Grundtvig skitserer i det følgende. Her redegør Grundtvig nemlig for, hvordan han var kommet til den overbevisning, at rationalisternes bibelkritik og skrifttolkning, skønt den var falsk, ikke kunne imødegås gennem en anderledes tolkning af skriften, hvor velfunderet den end var. Det ville blive påstand mod påstand, tolkning mod tolkning, og i den situation ville rationalisterne vinde slaget, fordi de var i overtal. Troen måtte have et andet grundlag end »Bogstav-Skriften«. Hvad dette grundlag er, går op for Grundtvig i »et velsignet Øjeblik « (Erindringer, s. 105): Troens grundlag er Den apostolske Trosbekendelse, som den lyder ved dåben. Den apostolske Trosbekendelse er nemlig »Ord til os af Herrens egen Mund " (Erindringer, s. 105), der har lydt som en »Himmel-Røst« (Erindringer, s. 105) gennem hele kristenhedens historie. I erindringerne henviser Grundtvig til Luther, som den, der har lært ham dette, men derimod ikke til Irenæus (Erindringer, s. 105). Denne opdagelse medførte ifølge Grundtvig, at rationalisternes skriftkritik og skrifttolkning mistede sin brod og farlighed for menigheden (Erindringer, s. 105).

Den beskrivelse af »den mageløse opdagelse«, som Grundtvig giver i sine erindringer, stemmer godt overens med, hvad man kan læse ud af to prædikener fra juli 1825, både hvad angår opdagelsens indhold og dens pludselighed. I prædikenen på ottende søndag efter Trin., d. 24. juli $1825^{24}$ prædiker Grundtvig over Mt. 7,15-21 om at vogte sig for de falske profeter. De falske profeter, ulvene i fåreklæder, er tidens rationalister, der giver sig ud for at være kristne, men dog er kristendommens fjender: "Ja, christne Venner, det er de falske Propheter for hvilke vi omhyggelig skal vogte os, dem der lægge Herren Jesus Christus og hans Apostler Ordene i Munden og beraabe sig derpaa, forkynde deres egen Viisdom, deres egen Daarskab, deres egne Drømme, og give Herren Skyld derfor, dem der ud- 
give for Christendom, hvad de selv har gjort, selv optænkt og sammenspundet, dem der kalde Jesum Herre men giør ikke Faderens Villie, som er at vi skal troe paa Sønnen, og have Livet i Hans Navn, dem der, som Jesus selv siger, kalder ham Herre, men vil dog ikke giøre, hvad han haver befalet sine Tjenere, vil ikke lære Menneskene at holde men at forkaste og fordreie hans Ord «. ${ }^{25} \mathrm{Hvad}$ kan de sande kristne så stille op mod disse falske profeter? Grundtvigs svar på denne søndag er: "...Guds Ords flittige Læsning under Aarvaagenhed og Bøn, det er det ufeilbarlige, men også det eneste Middel, hvorved vi kan vogte os for de falske Propheter,... «. ${ }^{26}$ Den 24 . juli kender Grundtvig altså ikke andet middel mod rationalisternes falske lære end flittig bibellæsning under bøn og årvågenhed.

Læser man nu den næste søndags prædiken fra d. 31 . juli ${ }^{27}$ er svaret et ganske andet. I ugens $l \varnothing b$ er der sket noget ganske afgørende. Grundtvig har opdaget trosbekendelsen. Hele stemningen i prædikenen viser, at der er sket noget ganske afgørende, hvad Grundtvig da også proklamerer: »...veed I det ikke, hvorledes Herren Trøster sit Folk, og giør Ende paa Tvivlraadigheden,..., veed I det ikke endnu, da hører mig nøie, da hører, hvorledes Herren har lært mig at trøste Hans Folk og tale kiærlig til Jerusalem, da hører, hvad jeg nu har lært at svare dem, der kalde sig Christi Apostler, Jesu Christi Tjenere, og vil dog røve ham Hans Guddoms-Ære... $\ll{ }^{28}$ Grundtvig fortsætter redegørelsen for sin opdagelse med at beskrive, hvordan han efter at have lidt skibbrud på barnetroen længe drev sovende omkring på havet for så endelig at vågne op og opdage dåbens nåde og nadverens velsignelse. Hvad er nu det afgørende i denne opdagelse af dåbens nåde og nadverens velsignelse? Det afgørende er opdagelsẹn af, at alle kristne til alle tider er blevet døbt i Faderens, Sønnens og Helligåndens navn. Til alle tider og overalt er mennesker blevet kristne, fordi de er blevet døbt på Den apostolske Trosbekendelses ord. Det gælder også Grundtvigs tilhørere. Det er altså dåben på Den apostolske Trosbekendelses ord, der er troens grundvold, og ikke én eller anden mere eller mindre korrekt fortolkning af de bibelske skrifter. Grundtvig havde imidlertid forudset, hvilke indvendinger, der ville komme, mod dette synspunkt: »Vel hører jeg, I sige, det skal staae i Bibelen, at denne vores, at denne alle Christnes Troes-Bekiendelse er falsk, men det er jo aabenbar Daarskab at tale saa, thi hvad der end staaer i Bibelen, saa er det jo lige vist og lige unægteligt, at den Tros-Bekiendelse, de Christne til alle Tider, i alle Menigheder 
har aflagt den og ingen anden er de Christnes Tros-Bekiendelse, saa hvem der vil nægte det, var det end en Engel af Himmelen, han lyver grovt $\ll .{ }^{29}$ En eventuel modsigelse mellem bibelen og trosbekendelsen ryster altså ikke Grundtvig. Han fastholder, at i så fald er det trosbekendelsen, der står fast, og bibelen, der må forkastes, fordi trosbekendelsen har historiens vidnesbyrd med sig. Imidlertid fremgår det af hans følgende bemærkninger, at han er overbevist om, at der ikke er nogen modsætning mellem bibelen og trosbekendelsen. Grundtvigs erindringer og disse to prædikener fra slutningen af juli 1825 stemmer altså overens i deres vidnesbyrd om såvel »den mageløse opdagelses « pludselighed som om dens indhold.

Denne beskrivelse af den "mageløse opdagelse « af trosbekendelsens betydning kunne tyde på, at overvindelsen af rationalisternes skriftkritik og skrifttolkning bestod $\mathrm{i}$ at bibelen blev sat helt til side og erstattet af Herrens ord, som det lyder i trosbekendelsen. Dette er ét - og sandsynligvis også det vigtigste - aspekt af »den mageløse opdagelse «: Bibelen mister sin fundamentale betydning som den grundvold de kristnes tro i sidste instans bygger på. Dermed mister rationalisternes trosnedbrynde bibelkritik og skrifttolkning naturligvis også sin betydning som en fundamental trussel mod troen. Der er imidlertid mere at sige til denne sag: selv om bibelen mister sin fundamentale betydning som den dybeste grundvold for de kristnes tro, betyder det ikke - heller ikke ifølge Grundtvig -, at den ganske mister sin betydning som vidnesbyrd om, hvad kristendom er. Grundtvig fastholder nemlig, som det fremgår af prædikenen til 9. sønd. e. trin. 1825 , at der er overensstemmelse mellem bibelens vidnesbyrd og trosbekendelsens indhold. Derfor skal bibelen stadig tolkes - og tolkes ret. I denne sammenhæng spiller opdagelsen af trosbekendelsen også en afgørende rolle, idet trosbekendelsen ifølge Grundtvig ikke blot er troens dybeste grundvold, men i konsekvens heraf også det kriterium, som tolkningen af skriften skal prøves på. At dette også er et afgørende aspekt af »den mageløse opdagelse « af trosbekendelsens betydning fremgår af fortalen til »Kirkens Gjenmæle«.

»Kirkens Gjenmæle ${ }^{30}$ udkom d. 5. sept. 1825. Bogen er en reaktion på prof. H.N. Clausens bog med titlen: »Catholicismens og Protestantismens Kirkeforfatning, Lære og Ritus«. Denne bog udkom d. 3. sept. 1825. Grundtvigs reaktion kom altså prompte. Skønt Grundtvig var hurtig med pennen, når det var nødvendigt, kan han næppe have skrevet sit modskrift i tidsrummet mellem d. 3. og d. 5. sept. 
Han må have fået bogen tidligere, sikkert fordi han subskriberede på den. Det forklarer også, hvordan fortalen til »Kirkens Gjenmæle«kan være dateret »Irenæi Dag«, som er den 26. august.

Det fremgår både af Grundtvigs erindringer (Erindringer, s. 104) og af fortalen til »Kirkens Gjenmæle « ${ }^{31}$, at han siden sin »mageløse opdagelse « i slutningen af juli 1825 har ventet på en lejlighed til at angribe rationalisterne, fordi han nu mente at kunne tilbagevise deres bibelkritik og skrifttolkning. Den førstgivne lejlighed er altså Clausens bog.

Skønt »Kirkens Gjenmæle « behandler en række forskellige problemstillinger f.eks. stat-kirkeforholdet, er der dog ingen tvivl om, at det afgørende for Grundtvig er at få foretaget et endeligt opg ør med rationalisternes bibeltolkning og bibelkritik. Det fremgår klart af fortalen, hvor det bl.a. hedder: »..., thi Hoved-Spørgsmaalet er ikke, hvis theologiske Mening der er den forsvarligste, men med hvad Ret en enkelt Theolog eller et heelt theologisk Selskab udgiver sin SkriftTolkning for den eneste rigtige, uden at kunne unægtelig, soleklart bevise det «. ${ }^{32}$ Det er altså spørgsmålet om, hvad der er ret skrifttolkning, og hvordan man afgør, hvad der er ret skrifttolkning, der er det centrale for Grundtvig. Lidt senere i fortalen gør Grundtvig anklagen mod Clausens skrifttolkning mere konkret: »Nu har Professor i Theologien H.N. Clausen i fornævnte Bog paa det Udtrykkeligste og Stærkeste erklæret, at han ei vil taale nogen anden KundskabsKilde eller Troes-Regel i den Christelige Kirke end Skriften, og ligesaa bestemt erklæret Skriften for usikker og Selvmodsigende, hvoraf unægtelig følger, at han ei alene forkaster den Cristelige Kirkes oprindelige Troes-Bekiendelse, men erklærer den giennem mange Aarhundreder bekiendte Christendom for aldeles ubekiendt og ukiendelig. Da han nu, desuagtet, ei blot vil hedde Christen, men giælde for en christelig Skrift-Fortolker, der kan lære Andre, hvad han, efter egen Bekiendelse, ikke selv veed: hvad der er ægte Christendom, saa maa han enten forsætlig ville bedrage sine Læsere og Tilhørere, eller han maa have været blind for de soleklareste Sandheder, og hvilken af Delene der er Tilfældet, maa han nu selv afgiøre, i det den klare unægtelige Sandhed foreholdes ham «. ${ }^{33}$ Det problematiske i rationalisternes skriftsyn og skrifttolkning er altså ifølge Grundtvig, at de både hævder, at bibelen er den eneste kilde til kundskab om, hvad sand kristendom er, og erklærer, at bibelen er usikker og selvmodsigende. Hvis det er sandt, gives der ikke noget 
fast grundlag for troen. Men det er ifølge Grundtvig heller ikke sandt. Det grundlæggende kriterium for, hvad der er sand kristendom er nemlig ikke bibelen, men kirkens »Grund-Bekiendelse « ${ }^{34}$, d.v.s. Den apostolske Trosbekendelse. Med dette som udgangspunkt kan Grundtvig tage kampen op mod Clausen og de andre rationalisters skrifttolkning, idet han »...herved lægger Professorens Bog ved Siden ad Kirkens Bekiendelse, og erklærer: de lade sig umulig forene «. ${ }^{35}$ Opdagelsen af trosbekendelsens betydning som troens fundament $f \varnothing-$ rer altså ikke til, at Grundtvig siger til Clausen, at han kan tolke bibelen, som han vil, for bibelen har ikke længere nogen betydning. Derimod fører opdagelsen til, at Grundtvig får et redskab i hænde, hvormed han endegyldigt kan afvise den rationalistiske bibeltolkning, som værende i modstrid med kirkens ældgamle tro.

$\mathrm{Nu}$ kommer jeg så til spørgsmålet om, hvad alt dette har med Irenæus at gøre. Min påstand er, at Grundtvig simpelthen har gjort denne helt afgørende opdagelse af trosbekendelsens betydning hos Irenæus. Denne påstand skal jeg begrunde: Grundtvig siger selv i fortalen til oversættelsen af Adv. haer. 5. bog $^{36}$, som udkom i 1827, at han begyndte at læse Irenæus for fire år siden, altså i 1823. Denne angivelse stemmer godt overens med de observationer man kan gøre i hans prædikener fra denne periode. E. Glenthøj fastslår således i sin artikel i Grundtvig Studier fra $1995^{37}$, at der med sikkerhed kan identificeres irenæiske motiver i Grundtvigs prædiken til midfastesøndag 1823. Samme angivelse for tidspunktet for de første irenæusmotiver finder man hos M. B. Christensen ${ }^{38}$ og K. Thaning ${ }^{39}$, der dog antyder, at Grundtvig kan have læst Irenæus allerede i slutningen af 1822. Da Grundtvig så i juli 1825 sad og "grublede, læste og skrev under Bøn og Påkaldelse«, som han skriver i erindringerne (s. 105), har en af de ting han læste været de første kapitler af Adv. haer. 1. bog. Ved denne læsning er det pludselig gået op for ham, hvilken fundamental rolle "sandhedens regel « spillede for Irenæus i hans kamp mod gnostikernes forvanskende skrifttolkning. Grundtvig har set, at hans kamp mod rationalisternes bibelkritik på dette punkt var en direkte parallel til Irenæus kamp mod gnostikerne. Og han har set, at Irenæus' løsning på problemet også kunne være hans løsning: Ligesom Irenæus brugte »sandhedens regel«, som blev indpodet i de kristnes hjerter ved dåben, som sammenfatning af kirkens overleverede tro og i forlængelse heraf som kriterium for, hvordan skriften skulle tolkes ret, sådan måtte Den apostolske Trosbekendelse, som 
alle kristne er døbt på, også nu betragtes som essensen af kirkens overleverede tro og derfor også som kriterium for, hvordan bibelen skal tolkes ret. For der er for Grundtvig ligesom for Irenæus overensstemmelse mellem bibelen og trosbekendelsen, mellem den skriftlige og den mundtlige tradition.

At dette ikke blot er min egen teori fremgår af fortalen til »Kirkens Gjenmæle«. Denne fortale afsluttes nemlig med følgende henvisning til Irenæus: »Jeg veed meget godt, man vil skrige Ak og Vee over mit Kiætter-Magerie, som man kalder enhver Protest, Kirken giør mod sine falske Venner, men jeg veed ogsaa, man skal n $\varnothing$ des til at indrømme, at det Slags Kætter-Magerie har man ikke seet for nyelig, vel ikke siden den Bog blev skrevet, hvoraf jeg har lært det, det er Irenæi velsignede Bog til Kirkens Forsvar, som egentlig først nu kan forstaas og benyttes « ${ }^{40}$ Grundtvig angiver altså klart og tydeligt, hvor han har lært, hvordan kætternes falske skrifttolkning skal tilbagevises, nemlig hos Irenæus. Ikke nok med det: fortalen til »Kirkens Gjenmæle« er, som nævnt, dateret »Irenæi Dag 1825«, hvilket må betragtes som en klar anerkendelse af den rolle, som Irenæus har spillet for Grundtvigs opdagelse af trosbekendelsens funktion som sammenfatning af de kristne grundlærdomme og som kriterium for skrifttolkningen.

Udsagnene i »Kirkens Gjenmæle« er egentlig tilstrækkeligt bevis for den rolle, som Irenæus har spillet for Grundtvigs »mageløse opdagelse«. Alligevel skal jeg ikke undlade at henvise til en endnu uudgivet tekst fra Grundtvig-arkivet ${ }^{41}$, hvori Grundtvig har nedfældet en række citater og korte referater fra Adv. haer. 1. og 3. bog. Bl.a. refererer Grundtvig begge de lignelser fra Adv. haer. 1,8,1 og $1,9,4$, som Irenæus anvender til beskrivelse af gnostikernes falske skrifttolkning, ligesom han også refererer Irenæus' henvisning til »sandhedens regel«, som kriterium for de kristnes afvisning af denne falske skrifttolkning. Disse excerpter godtgør altså, at Grundtvig har været opmærksom på Irenæus' brug af »sandhedens regel« som kriterium for skrifttolkningen. Disse excerpter er ikke dateret, men jeg vil vove at foreslå en datering, der lyder: ugen mellem 24 . og d. 31 juli 1825. Holder denne vovelige påstand ikke, vil jeg dog mene, at de utvivlsomt må være blevet til i tidsrummet 1823-25 som en væsentlig forudsætning for »den mageløse opdagelse «.

Endelig må jeg også henvise til de gentagne sammenligninger mellem gnostikerne og rationalisterne specielt m.h.b.p. deres bibel- 
tolkning, som Grundtvig foretager i noterne til sin oversættelse af Adv. haer. 5. bog fra $1827 .{ }^{42}$ Disse sammenligninger viser, at netop spørgsmålet om skrifttolkningen har stået i centrum for Grundtvigs interesse for Irenæus - også i tiden efter »den mageløse opdagelse«.

Jeg mener altså at kunne give gode grunde til at antage, at Grundtvigs »mageløse opdagelse« på en meget direkte måde er inspireret af hans irenæus-læsning.

Noter

1 Det drejer sig f.eks. om følgende motiver: menneskets gudbilledlighed; sammenhængen mellem skabelsen og fuldendelsen; Adam-Kristus typologien; væksttanken og forestillingen om, at mennesket blev skabt som et barn. Ang. Grundtvigs benyttelse af disse motiver, se M.B. Christensen: N.F.S Grundtvigs Irenæuspåvirkning, Århus 1992; A.C. Jacobsen: Skabelse og fuldendelse hos Irenæus - med et udblik til Grundtvig, Præsteforeningens Blad, 1996/21, s. 429-438; K. Thaning: Grundtvigs møde med Irenæus, Grundtvig Studier 1953; N. Thomsen: Grundtvig i oldkirkens spejl, Grundtvig og grundtvigianismen i nyt lys (red. C. Thodberg og A. Pontoppidan Thyssen), Århus 1983, s. 197-209.

2 Dog har J.H. Schjørring redegjort for, hvordan Irenæus' henvisning til skriften, trosbekendelsen og det kirkelige embede som de tre grundpiller hvorpå kirkens lære bygger, har været en inspirationskilde for Grundtvig, jvf. J.H. Schjørring: Grundtvigs billedsprog - og den kirkelige anskuelse, Kbh. 1990, s. 87-112. Schjørring hævder imidlertid på trods af en præcis redegørelse for, hvordan Irenæus har inspireret Grundtvig i tiden omkring 1825, at: »Indtrykkene af Irenæus udløste ikke noget »gennembrud« hos Grundtvig og lader sig derfor slet ikke afgrænse præcist« (op.cit., s. 104). I modsætning hertil mener jeg, at Grundtvigs læsning af Irenæus har været en direkte medvirkende årsag til gennembruddet i 1825.

3 Den bedste introduktion til Irenæus' teologi er stadig G. Wingrens bog »Människan och inkarnationen enligt Irenaeus «, Lund 1947. Desuden også G. Wingren: Människa och kristen. En bok om Irenaeus, Arlöv 1983 og D. Minns: Irenaeus, London 1994.

4 Den nyeste og bedste fuldstændige udgave af grundteksten til Adv. haer. er: A. Rousseau og L. Doutreleau: Irénée de Lyon, Contre les Hérésies, som er udkommet i serien: Sources Chrétiennes, Paris 1965-82. Denne 
udgave indeholder en fransk oversættelse. Desuden er skriftet oversat til tysk af E. Klebba, Bibliothek der Kirchenväter, Bd. 1-2, Kempten og Muenchen 1912; til engelsk af A. Roberts og J. Donaldson, The AnteNicene Fathers, Vol. 1, Michigan 1989 (genoptryk). Endelig er Adv. haer. 5. bog oversat til dansk af N.F.S. Grundtvig: Om Legemets Opstandelse og Deel i Guds Rige, Theologisk Maanedsskrift, Ellevte Bind, udgivet af A.G. Rudelbach, Kbh. 1827; ny udgave: Kiødets Opstandelse og det evige Liv, Kbh. 1855.

5 Teksten er oversat fra armenisk til dansk af J.P. Asmussen: Irenæus' Bevis for den apostolske forkyndelse. Oversættelse fra armenisk, indledning og noter, Kbh. 1970.

6 Ang. sandhedens regel hos Irenæus, se Sv.A. Becker: O KAN $\Omega$ N TH $\Sigma$


Kelly: Early Christian Creeds, s. 76-82.

7 Grundtvigs Erindringer og Erindringer om Grundtvig. I Uddrag ved S. Johansen og H. Høirup, Kbh. 1948. I det følgende forkortet: Erindringer.

$8 \quad$ Ang. Grundtvigs teologiske udvikling indtil 1825, se E. Albinus Glenth $\varnothing$ j: Grundtvigs teologiske udvikling til omkring affattelsen af »De Levendes Land«, Grundtvig Studier 1995, s. 217-74; K. Thaning: Grundtvigs møde med Irenæus, Grundtvig Studier 1953, s. 7-68; C. Thodberg og A. Pontoppidan Thyssen: Kort Biografi, Grundtvig og grundtvigianismen i nyt lys, Århus 1983, s. 9-16; A. Pontoppidan Thyssen: Grundtvigs tanker om kirke og folk, Grundtvig og grundtvigianismen i nyt lys, s. 84-114; 225-86.

G. Christensen og H. Koch: N.F.S. Grundtvig, Værker i Udvalg (herefter V.U.), bd. 1, Kbh. 1940, s. 103-39.

10 N.F.S. Grundtvig: Bibelske Prædikener (herefter B.P.), Kbh. 1816. Her citeret efter udgaven fra 1883.

11 V.U., bd. 1, s. 335-480.

12 Se f.eks. V.U., bd. 1, s. 406-408; 420-21; 441; 450.

13 Søndag sexagesima 1815 , B.P., s. 272-291.

${ }^{14}$ C. Thodberg: Grundtvig som prædikant, Grundtvig og grundtvigianismen i nyt lys, s. 117-162. 
15 C. Thodberg: op.cit., s. 129. Om Grundtvigs brug af billedsproget, se endvidere J.H. Schjørring: Grundtvigs billedsprog og den kirkelige anskuelse, Kbh. 1990.

16 Grundtvigs Præst $\varnothing$ Prædikener, udgivet af C. Thodberg, Kbh. 1988, bd. 1, s. 310-11. Hele bekendelsesudsagnet er udskrevet som prosa-digt af C. Thodberg, op.cit., s. 63-65 og i artiklen: Grundtvig som prædikant, Grundtvig og grundtvigianismen i nyt lys, s. 131-33.

17 Præst $\varnothing$ Prædikener, bd. 1, s. 314.

18 Grundtvigs Prædikener (herefter forkortet G.P.), udgivet af C. Thodberg, bd. 2, Kbh. 1983, s. 42-49.

19 G.P., bd. 2, s. 42.

20 G.P. bd. 2, s. 46. Afsnittet er udskrevet som prosadigt af C. Thodberg, G.P. bd. 2, s. 8; og i artiklen: Grundtvig som prædikant, Grundtvig og grundtvigianismen i nyt lys, s. 156-57.

${ }^{21}$ G.P., bd. 2, s. 8; Grundtvig som prædikant, Grundtvig og Grundtvigianismen i nyt lys, s. 157.

22 Det drejer sig især om den utrykte »Brevveksling mellem Nørre-Jylland og Christianshavn « fra foråret 1824 (fasc. 99), hvor Grundtvig allerede taler om Irenæus' betydning som vidne om den sande kristendom, og om bekendelsens og den mundtlige traditions betydning. Se herom: H. Høirup: Grundtvigs Syn på Tro og Erkendelse, Kbh. 1949, s. 175-226; K. Thaning: Grundtvigs møde med Irenæus, Grundtvig Studier 1953, s. 12.

23 Ang. Grundtvigs »magel øse opdagelse«, se K. Baag ø: Grundtvigs Magel øse Opdagelse. Et bidrag til dens tilblivelseshistorie, Grundtvig Studier 1957, s. 36-50, hvor i Baagø påpeger, at der, allerede før Grundtvig gjorde sin opdagelse af trosbekendelsens betydning, var en debat i gang om symbolerne både herhjemme og i Tyskland. Endvidere K. Thaning: Den »mageløse opdagelse«s tilblivelse, Grundtvig Studier 1981, s. 7-29. I denne artikel beskriver Thaning, hvordan den »mageløse opdagelses « tilblivelse kan aflæses af en række udkast til 4. del af afhandlingen »Om den sande Christendom og Christendommens Sandhed « som blev skrevet i 1824. Endelig A. Pontoppidan Thyssen: Grundtvigs tanker om kirke og folk 1825-47, Grundtvig og grundtvigianismen i nyt lys, s. 225-233.

G.P., bd. 3, s. 199-202. 
26 G.P., bd. 3, s. 200 .

27 G.P., bd. 3, s. 202-211.

28 G.P., bd. 3, s. 207.

29 G.P. bd. 3, s. 209.

30 V.U., bd. 2, Kbh. 1941, s. 317-49. Ang. »Kirkens Gienmæle«, se T. Jørgensen: Grundtvigs »Kirkens Gienmæle« - læst i nutidigt perspektiv, Grundtvig Studier 1992, s. 46-66. Senere trykt i: T. Jørgensen: Korset i Altet, Kbh. 1995, s. 177-196; og i engelsk oversættelse: Heritage and Prophecy, s. 171-190. I denne artikel giver Theodor Jørgensen en yderst interessant redegørelse for de systematisk-teologiske perspektiver i Grundtvigs opdagelse af trosbekendelsens betydning.

31 V.U., bd. 2, s. 320-21.

32 V.U., bd. 2, s. 319.

33 V.U., bd. 2, s. 320.

34 V.U., bd. 2, s. 319.

35 V.U., bd. 2, s. 318.

36 „Om Legemets Opstandelse og Deel i Guds Rige«. Trykt i Theologisk Maanedsskrift, udgivet af A.G. Rudelbach, Ellevte Bind, Kbh. 1827, s. 7.

37 E. Albinus Glenthøj: Grundtvigs teologiske udvikling til omkring affattelsen af »De Levendes Land«, Grundtvig Studier 1995, s. 231 note 36.

38 M.B. Christensen: N.F.S. Grundtvigs Irenæuspåvirkning, Århus 1992, s. 5.

39 K. Thaning: Grundtvigs møde med Irenæus, Grundtvig Studier 1953, s. 1016.

40 V.U., bd. 2, s. 321 
41 Denne tekst (Ny kgl. Saml. 3647 I $4^{0}-2$ B 4) bearbejdes i øjeblikket af $\mathrm{U}$. Kiel og vil foreligge transskriberet og kommenteret i Grundtvig Studier 1997.

42 »Om Legemets Opstandelse og Deel i Guds Rige«, Theologisk Maanedsskrift, udgivet af A.G. Rudelbach, Ellevte Bind, Kbh. 1827, s. 206 note 2; 216 note $1 ; 249$ note 1 . 